\title{
At the receiving end: Are policies and practices working to keep students in high schools?
}

\section{ViJAYA M. DHARAN, LUANNA H. MEYER, AND NiCOLE MiNCHER}

Exclusion occurs when school systems do not have the answers, or are often unwilling to delve deeply into the primary source of the behaviours in focus. "Exclusion, intolerance, "getting rid of', 'not my responsibility', blame, are all symptoms of projection - projected guilt; guilt over dilemmas we don't know how to solve” - (Parffrey, 1994, p.117). Two decades later these words still ring true in our education system.

\section{Introduction}

recent media report from the Ministry of Education on stand1 are the "lowest in 12 years of recorded data" (Fletcher, 2012). While the news is heartening, the findings also show that Māori and Pasifika students continue to fare high on these lists, which calls for a re-examination of the reasons behind this continuing trend. There is now more than ever before quality research information available on evidence-based best practices of what works and why for this population of students, both nationally and internationally (Sleeter, 2011). Despite having this kete of indigenous and wider wisdom available, why we continue to have such a dismal record for Māori and Pasifika students in high schools requires critical scrutiny and urgent interventions. Given the size of this student population, admittedly diverse, why are we in New Zealand not able to provide learning environments that will support the participation and learning of all students? These questions underpin the article and are triggered 
by the drive and desire to have an education system that can espouse and enact fairness and equity. This article focuses on stand-downs and suspensions among the disciplinary quartet of stand-downs, suspensions, expulsions, and exclusions ${ }^{1}$ - categories under which students are alienated from their natural learning environments. The rationale is that if the number of stand-downs and suspensions were reduced in the early stages, then the number of students excluded or expelled would drop, thereby enabling more students to remain in school and connected with their learning. The article briefly explains the major initiatives undertaken by the government to reduce the ethnic disparity in disciplinary statistics over the past decade. It presents some quantitative New Zealand data of disciplinary statistics spanning a decade on stand-downs and suspensions. The article examines literature in the area of disciplinary measures, and some of the programmes and approaches used both in New Zealand and overseas as alternative strategies to reduce the number of out-ofschool suspensions. It also identifies the need for further research to understand more clearly the category of "continual disobedience" which has no clear definition. Finally, the article argues for a more within-school approach to deal with behavioural challenges to prevent students moving through the disciplinary hierarchy of stand-downs $\rightarrow$ suspensions $\rightarrow$ expulsions.

\section{Education Act and discipline}

Disciplining in schools is by no means an unregulated act. The Education Act 1989 (sections 13-19) outlines the process and product of suspensions. It details all the necessary steps that are to be taken by the principals of schools before a student is suspended, either for a specified period (up to 3 days), or for an unspecified period of time, pending various enquiries and actions by the Boards of Trustees (Casey, 1994). Although involving the family was compulsory, often Boards of Trustees and principals had the "discretion to interpret the Education Act” (Casey, 1994, p. 278).

In an attempt to wrest the entire decision-making process of suspensions from schools and with the growing momentum of the

See Appendix 1 for explanation of the terms 
United Nations Convention on the Rights of the Child, the Act was amended in 1998 to allow the process of suspending students to be more democratic by making it a more consultative process with families and the students themselves. There was more flexibility for principals with the increase in the allowable stand-downs (for up to five days), which provided an intermediary step to re-examine issues of behaviour and its consequences (Rae, 1999). The emphasis of this amendment was to ensure that each case of disciplinary action was dealt with in accordance with the principles of natural justice. These principles continue to underpin the current guidelines (Ministry of Education, 2009) which provide details of the legal option and duties for principals and boards of trustees on the subject of stand-downs, suspensions and expulsions.

Often, exclusionary discipline practices are the product of dilemmas that schools are in, as they have to make a call on an “individual's right to education or the majority's right to schooling in contexts that are safe and affirming” (Wearmouth, Mckinney, \& Glynn, 2007, p. 196). At the same time, the principal and board also have the duty to ensure that "all students have assistance to remain at school and progress with their learning (Ministry of Education, 1991, p. 3, cited in Casey, 1994) before suspending a student. Section 13 of the Education Act requires schools to provide a range of responses and also minimise the disruption to a student's attendance.

\section{Disciplinary statistics over time}

Disciplinary statistics for the three-year period 1989 - 1991 immediately following Tomorrow's Schools showed a steady increase in suspension rates of students (Casey, 1994). Extending the time period through 1992-1996, Rae (1999) noted an almost 100\% increase in rates of suspension. Specifically quoting statistics from the Ministry of Education, he reported that "the suspension rate per 1000 students increased from 9.3\% in 1993 to $16.8 \%$ in 1997” (p. 37). Although age standardised stand-down, suspension and exclusion rates are now lower in comparison, the numbers are still high and there is no change to the rates of the ethnic groups that are most vulnerable in terms of schools’ disciplinary procedures, that is, Māori and Pasifika. 


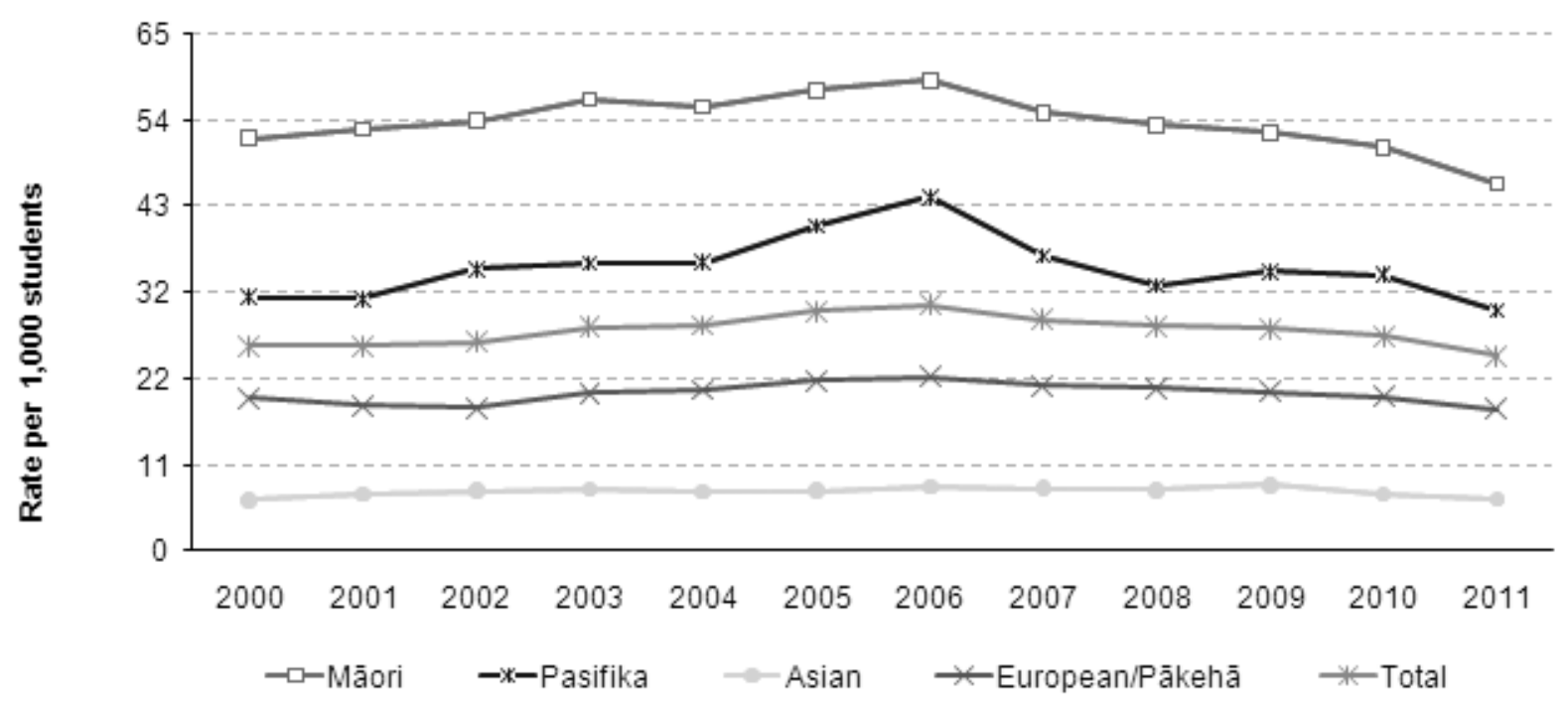

Figure 1- Stand-downs

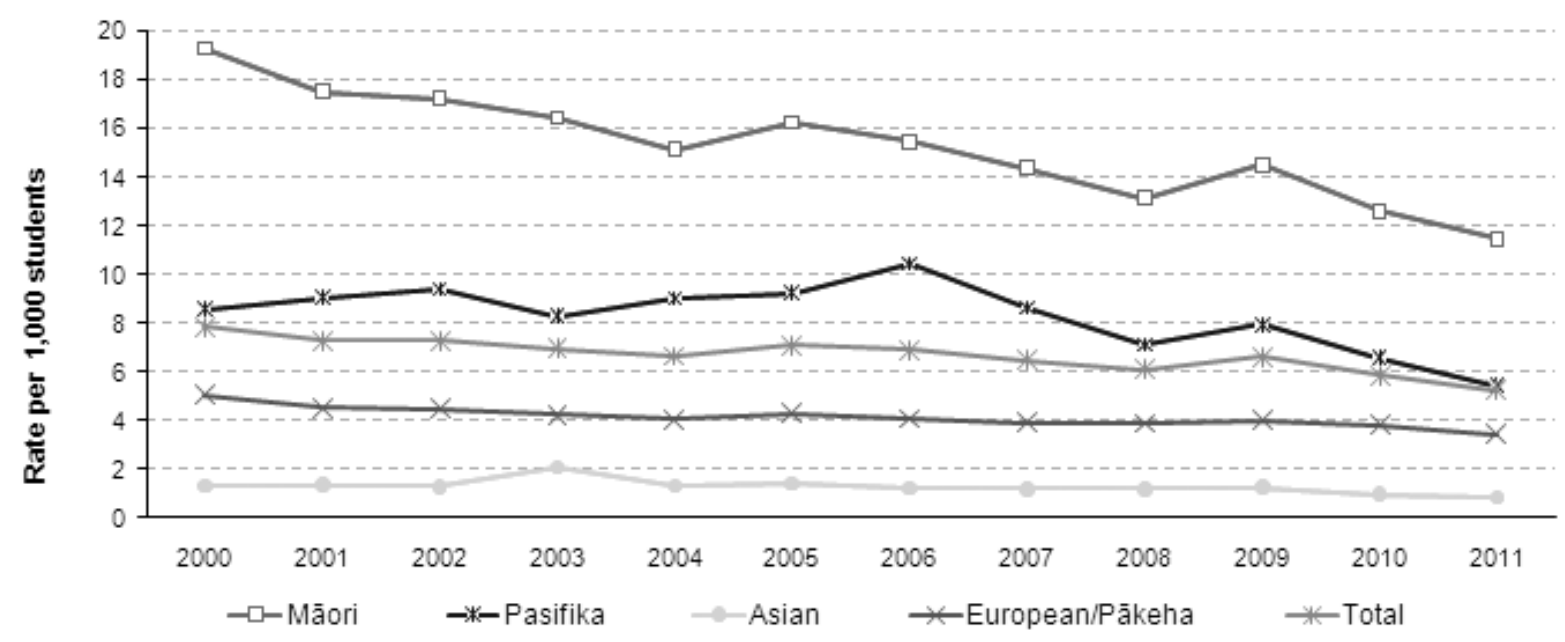

Figure 2 Suspensions

Although the suspension rates for Māori are shown as decreasing (from 19.2 per 1000 in 2000, to 11.4 in 2011), the age-standardised suspension rate for Māori students (11.4 suspensions per 1,000) was over twice as high as for Pasifika students (5.4 suspensions per 1000) (Ministry of Education, 2012). Though there is a slight reduction in the number of students suspended, both stand-downs and suspension data over the past decade have a common trend:

- Males and Māori remain over-represented in the statistics.

- Young people aged 13 to 15 years are over-represented in both stand-downs and suspensions with age 14 being the most vulnerable year. 
- Behaviours that resulted in stand-downs and suspensions broadly fall into three categories: continual disobedience, physical assault and drug related offences.

In 2011, continual disobedience was the main reason for suspensions (25.7\%), with an age standardised rate of 1.3 per 1000 students. The second main reason was drugs (including substance abuse) at 1.2 per 1000 students (22.6\% of total). Along with physical assault on other students (1.0 per 1000 students or $18.9 \%$ ), these behaviours made up over two-thirds of all suspensions. "Other" behaviours included sexual harassment, sexual misconduct, weapons, and other harmful and dangerous behaviours. (Ministry of Education, 2012)

The category of continual disobedience alone accounts for a significant number of stand-downs, suspensions and even exclusions and expulsions. Continual disobedience is defined as deliberately and regularly failing to do what you are told and a student's behaviour must set a harmful or dangerous example to other students to meet this criterion (Ministry of Education, 2009). It is indeed interesting to note that the definition of this category has its origin in Youth Law just as zero tolerance policies in schools originated as "one form of national crime policy" (Casella, 2003, p. 873). However, the lack of specificity of this category has led to its interpretations being highly contextualised allowing a wide range of behaviours such as truancy, disruptive behaviour, non-compliance, and even tardiness to fit into this category (Hemphill et al., 2012; Skiba \& Sprague, 2008; Vavrus \& Cole, 2002). In these circumstances, this category within the disciplinary process requires more scrutiny and empirical research in our schools to provide teachers and other school personnel with clarity and to make behavioural expectations transparent to students. As Macfarlane and Margrain (2011) observe:

Many of the current educational processes and practices are not working for a large and growing percentage of the student body indeed, they may inadvertently be serving to perpetuate alienation and underachievement for many students. (p. 7)

\section{Initiatives to increase student engagement}

Over the years there have been efforts by the Ministry of Education in New Zealand to address concerns around ethnic disproportionality in 
disciplinary statistics by introducing in 2001 a series of initiatives under the banner of Suspension Reduction Initiatives (SRI), and in 20032 Student Engagement Initiatives (SEI). The SRI involved schools working in clusters to reduce suspension rates particularly aimed at reducing the number of Māori students being suspended. Funding was targeted at various levels - towards professional development for teachers, provision of support to school principals and boards, and support for students themselves. Rather than a prescribed programme or approach, initiatives were devised locally as dictated by the needs of the communities and schools and funded accordingly. In addition, this initiative saw the establishment of some youth mentoring programmes (He AraTika), social workers in schools, Strengthening Families initiative; and more specialised teacher support for students with behavioural problems. Homework centres were established in some schools to support students' learning. There was an Innovation funding pool available for schools that designed specific programmes to improve educational outcomes for 'at-risk' youth as well as funding for alternative education programmes for students under 16 who were alienated from the regular school system (Mallard, 2001). There was also funding for a parents' advocacy phone service through the Office of the Commissioner of Children and Wellington Community Law.

SEI was launched in 2003 to support schools to increase student participation by building upon successful suspension reduction initiatives. Given the higher suspension rates for Māori students and those students in lower decile schools, these initiatives particularly targeted schools in lower socio-economic areas with a high Māori student population. There were also other specific programmes to address bullying, drug use, and school violence - Kia Kaha, an antibullying kit that teachers could use as a teaching and learning resource about bullying which is still used in some schools. DARE was targeted at drug prevention although it is no longer widely implemented. Yet these initiatives have not resulted in the expected level of decrease in the unequal ethnic distribution of students in the disciplinary data.

\footnotetext{
${ }^{2}$ For more details on SRI \& SEI visit www.minedu.govt.nz
} 


\section{Persistence of the problem}

Despite such initiatives, the demographic trends in school disciplinary processes continue to mirror international patterns of inequity. Boys, minority ethnic groups and students in low socioeconomic area schools continue to be disproportionately represented in discipline samples (Ministry of Education, 2012; Monroe, 2006; Peguero \& Shakarkhar, 2011; Skiba, Michael, Nardo, \& Peterson, 2002). Even more concerning is that children as young as five years are suspended. We also have anecdotal and news stories of even preschoolers being suspended, although no official data have been collected or reported in this non-compulsory sector. The table below illustrates the ages and number of students suspended as part of disciplinary procedures in the period 2000-2011.

Table - 1: The number of suspension cases by age from $2000-2011^{*}$

\begin{tabular}{lrrrrrrrrrrrr}
\hline Age & $\mathbf{2 0 0 0}$ & $\mathbf{2 0 0 1}$ & $\mathbf{2 0 0 2}$ & $\mathbf{2 0 0 3}$ & $\mathbf{2 0 0 4}$ & $\mathbf{2 0 0 5}$ & $\mathbf{2 0 0 6}$ & $\mathbf{2 0 0 7}$ & $\mathbf{2 0 0 8}$ & $\mathbf{2 0 0 9}$ & $\mathbf{2 0 1 0}$ & $\mathbf{2 0 1 1}$ \\
\hline $\mathbf{5}$ & 3 & 4 & 2 & 1 & 4 & - & 7 & 6 & 4 & 3 & 5 & 3 \\
$\mathbf{6}$ & 11 & 8 & 6 & 13 & 16 & 10 & 18 & 19 & 14 & 9 & 20 & 15 \\
$\mathbf{7}$ & 20 & 20 & 25 & 27 & 27 & 25 & 25 & 21 & 31 & 35 & 15 & 20 \\
$\mathbf{8}$ & 38 & 30 & 45 & 54 & 50 & 47 & 59 & 54 & 47 & 47 & 32 & 42 \\
$\mathbf{9}$ & 57 & 60 & 74 & 67 & 66 & 79 & 80 & 90 & 69 & 67 & 71 & 47 \\
$\mathbf{1 0}$ & 110 & 121 & 112 & 114 & 79 & 133 & 122 & 124 & 103 & 97 & 91 & 75 \\
$\mathbf{1 1}$ & 215 & 214 & 207 & 199 & 196 & 202 & 219 & 213 & 208 & 184 & 191 & 166 \\
$\mathbf{1 2}$ & 412 & 391 & 466 & 438 & 403 & 454 & 477 & 479 & 472 & 394 & 291 & 339 \\
$\mathbf{1 3}$ & 1054 & 1017 & 1110 & 985 & 988 & 1103 & 905 & 895 & 843 & 898 & 727 & 616 \\
$\mathbf{1 4}$ & 1565 & 1441 & 1432 & 1501 & 1489 & 1553 & 1436 & 1314 & 1186 & 1337 & 1187 & 894 \\
$\mathbf{1 5}$ & 1072 & 990 & 956 & 1005 & 1002 & 1078 & 1100 & 974 & 919 & 1105 & 1043 & 992 \\
$\mathbf{1 6}$ & 420 & 356 & 357 & 339 & 313 & 337 & 382 & 349 & 311 & 429 & 386 & 334 \\
$\mathbf{1 7}$ & 111 & 115 & 113 & 114 & 121 & 111 & 131 & 108 & 140 & 133 & 149 & 117 \\
$\mathbf{1 8}$ & 17 & 36 & 29 & 43 & 30 & 17 & 34 & 36 & 39 & 35 & 16 & 36 \\
years+ & & & & & & & & & & & &
\end{tabular}

*Source Ministry of Education, official communiqué. Data incomplete at time of compilation. 


\section{Contributing factors to alienation}

There are both school related and external factors that contribute to lower school engagement. Internationally, schools in lower socioeconomic areas tend to have higher rates of suspensions and standdowns and have poorer academic results (Ainscow, 2012; Cavanagh, 2009). In Australia, Hemphill et al. (2010) found that the average rate of school suspensions drops as socio-economic status of the area increases. This was found to be true even when negating factors such as antisocial behaviour, gender and age were controlled, leading to an acknowledgement that there are external factors that can put students at higher risk of school removal. In New Zealand, decile 1-6 schools have the highest rates of suspension while deciles 9 and 10 have the lowest rates of suspension (Ministry of Education, 2012, official communiqué).

While external factors can contribute to ways students (mis)behave, which are often seen as insurmountable, there are some identified school related factors that can exacerbate alienation. Examining such school related factors can be helpful in identifying ways to assist students with behavioural difficulties. It is an established fact that attitudes, perceptions, and actions of school staff play a significant role in creating a nurturing ethos in schools. Therefore, their day-to-day pedagogical practices and school policies around ways to address behaviours are critical indicators of the school environment. Actions of principals and teachers rather than student behaviours have been shown to contribute to the variation in suspension rates in schools (Glynn \& Berryman, 2005; Hyman \& Perone, 1998; Kajs, 2006; Monroe, 2006; Parsons, 2011; Riordan, 2008). Policies, particularly Zero Tolerance, a stance that is espoused by some principals in New Zealand, have also contributed to an increase in exclusionary discipline practices (Casella, 2003; Gregory, Cornell, \& Fan, 2011; Skiba, 2000; Skiba \& Peterson, 2003). In fact, the notion of zero tolerance not only shows that schools will not tolerate student misbehaviours, but ironically also exposes the inflexibility or inability of school leaders to be creative and strategic problem solvers. As a result, under this approach schools have tended to take a very punitive and pedantic stance in dealing with student 
misbehaviours, without considering the long-term implications (Casella, 2003; Kajs, 2006; Martinez, 2009).

Though they are the recipients of disciplinary measures, students' voices with regards to what works in terms of discipline are seldom heard. When they were consulted, some of the factors students identified as leading to their exclusion are related to difficulties with academic work, a lack of relationship with teachers, and inability to relate to the ethos of the school (Brooking, Gardiner, \& Calvert, 2009; Casella, 2003; Hilton, 2006; O’Brien, Thesing, \& Herbert, 2001). There is also evidence that schools that over-rely on punitive discipline have unclear rules and, more importantly, do not involve students which is often counterproductive to reinforcing positive behaviours (Mayer, 2001; Reinke \& Herman, 2002; Skiba \& Sprague, 2008). It is apparent that listening to students and addressing their concerns is pivotal for initiating, and for the success of, disciplinary measures in any school. There is also substantial evidence that underscores the importance of creating a school ethos where students experience a sense of belonging (Cavanagh, 2007; Evans \& Harvey, 2012; Monroe, 2005).

\section{Consequences of non-engagement}

Despite widespread acknowledgement, it is necessary to reiterate the universal evidence of the social costs of disengaged youth (Becroft, 2012; Hemphill et al., 2012; Skiba \& Sprague, 2008; Skiba et al., 2003; Vulliamy \& Webb, 2000). Yet students who are deemed problematic are often not tolerated in schools and are de-linked from their natural learning environment quite early in high school. As a result, these students who are already vulnerable in terms of their life circumstances are made more vulnerable when their rights to education are curtailed (Hemphill et al., 2012; Monroe, 2006; Parffrey, 1994). This alienation from their education merely starts the process of re-locating the problem to another part of the community, without addressing underlying issues of the behaviours (McGee, 2012; Skiba et al., 2003). A recent review of literature on schools' responses to behaviourally challenging students emphasises the broader consequences for schools and their communities as a result of 
excluding students from their learning environment (Michail, 2011). Some unintended and often unavoidable effects of alienating students from educational contexts include a decline in self-esteem that quickly spirals into a diminishing vortex of self-discipline increasing avoidance behaviour, developing animosity and defiance, and subsequently reducing the chances of their academic success (Brooking et al., 2009; Hilton, 2006; Mayer, 2001; O’Brien et al., 2001).

Schools that are faced every day with disciplinary matters can argue and justify the use of punitive and exclusionary practices as a way to protect the learning of the majority of students. But mounting evidence regarding the long-term social costs of such punitive measures is edging schools to explore the use of alternative and more positive disciplinary approaches that can redeem young adults' ability to stay connected with their learning and, more importantly, their school community.

\section{Ways forward}

The literature is decisive in stating that the most successful measures to reduce out-of-school suspensions are those that have a systemic approach in which all school staff are involved, provide appropriate learning opportunities for students, and involve families as well as students in all aspects of managing learning and behaviours (Charlton, Panting, \& Willis, 2004; Glynn \& Berryman, 2005; Hallam \& Castle, 2001; Sanders, 2001; Savage, Lewis, \& Colless, 2011; Wearmouth et al., 2007). There is also substantive and conclusive evidence to show that existing ways of disciplining students and non-tolerant policies are ineffective; they do not serve to improve school contexts, nor do they have any positive impact on the long-term trajectory of students, particularly Māori and Pasifika students in New Zealand. Therefore, there is a sense of urgency to expedite alternative approaches to discipline that will keep students engaged and connected with their learning. As more recent evidence, a study of students in alternative education in New Zealand identifies the extent to which some students feel disconnected, disengaged and alienated in their high schools (Brooking et al., 2009). What is even more disconcerting was that 
some of these students did not see themselves as being able to return to mainstream education; some seem to have lost hope about being useful and productive citizens as adults. Thus, this paper argues for a positive approach utilising in-school alternatives as a way forward to reduce school dropout rates. The key to a preventative approach is to understand the causes for misbehaviours. A number of social, cultural and psychological reasons other than academic difficulties could manifest in misbehaviours of students, and a better understanding of the contextual relationship to student behaviours can lead to more inclusive ways of working (Brooking et al., 2009; Haley \& Watson, 2000; Monroe, 2005; O’Brien et al., 2001). Some of the nonexclusionary options are discussed below.

\section{In-school alternatives}

The concept of In-School Suspension (ISS) is not new. Retaining students within the boundaries of the school gate through an in-school suspension process has been a tried alternative to traditional disciplinary approaches. As the name suggests, first and foremost the approach eliminates the notion of physically alienating students from the premises of their learning but still does not go far enough in terms of isolating students. Although the key intent of the ISS approach is to ensure that students are not disengaged from their learning, students still feel alienated and perceive no benefit of being removed from their learning environment (Brooking et al., 2009; Dickinson \& Miller, 2006). So, it is important to design the ISS in ways that actually benefit students, because though students may be within the gates of their school, it could still mean a loss of academic learning time. Historically, schools overseas have approached an ISS system in three different ways - punitive, academic, and therapeutic (Haley \& Watson 2000; Michail, 2011; Morris \& Howard, 2003). In the punitive approach students are placed in a restrictive environment for 2-10 days where they spend their time completing assignments and also doing some punitive [community] work like picking up rubbish around the school. In the academic approach misbehaviours that arise out of learning difficulties are addressed by providing students with individual instructions and supporting with required resources. Haley and Watson (2000) observed ISS being used to foster literacy skills 
that had a dual purpose. It provided both a cathartic outlet for the underlying reasons of their disruptive behaviour, while also providing the platform for developing their writing skills. The third approach is a therapeutic one in which teachers talk with students about the causes of their misbehaviour. It is based upon the assumption that the behaviours are a result of problems in their lives and it is aimed to build their self-image, and problem-solving and communication skills in the school environment. Counselling is an important component of this approach. Though an effective ISS is a combination of the above three approaches (Michail, 2011), even this may not be effective unless the students see a purpose and value for both their withdrawals and the counselling offered (Brooking et al., 2009). Therefore, inschool suspension is more than withdrawing students from their regular classroom to another physical space. What would be more effective for students with behavioural difficulties is to have a place within their schools that provides a sense of belonging, and students perceive the ethos of the school as understanding and nurturing their social, cultural, and emotional well-being (Evans \& Harvey, 2012; Meyer \& Evans, 2012a; Shirley \& Cornell, 2012). Other critical factors identified for reducing exclusionary disciplining are the placements of students in appropriate courses, both academic and vocational, with appropriate instructional materials and combined with programmes for personal growth and development (Charlton et al., 2004; Parsons, 2011; Sanders, 2001).

Key aspects for a successful ISS programme include the number of staff involved in planning and implementation, financial support for schools, a rehabilitative focus to disciplinary procedures, and clearly defined objectives of the support programme to which the whole school staff are committed and have contributed (Sullivan, 1989). In other words, the initiative must be driven from within the school. As Meyer and Evans (2012a) observe, schools with a low exclusionary record tend to have a positive school culture that respects and holds positive images of students and their families, provides an emotionally safe school environment that optimises student learning and, more importantly, have a "proactive and preventative discipline approach rather than being oriented towards punishment” (p. 102). As with 
other alternative forms of behavioural management, relationships are a key component of an ISS programme as engaging students, and forming trusting relationships with their families allows teachers to influence student behaviour (Gootman, 1998; Haley \& Watson, 2000; Meyer \& Evans, 2012b). Once schools align their practices in ways that do not disconnect students from their learning environments, there are approaches that can support students that are more reconciliatory than punitive. While in-school alternatives may not yet be an established practice in New Zealand schools, anecdotally there are a number of within-school withdrawal practices for disruptive students, one school even calling it 'internal removals'. However, what is proposed as a way forward is an approach that can demonstrate changes to the demographic profile of our disciplinary statistics.

\section{Enablers of non-exclusionary discipline measures}

The ways put forward are not entirely new to schools. Some schools both in New Zealand and overseas have seen the futility and the social costs of excluding students, and have taken a more inclusive approach to dealing with behaviour challenges. Some of the non-punitive practices in such schools include:

\section{Restorative approaches}

Restorative approach and restorative conferences is an alternative model to exclusionary discipline practices (Macfarlane \& Margrain, 2011; Meyer \& Evans, 2012a, 2012b) that has a cultural fit with Māori Tikanga. ${ }^{3}$ Restorative practices are fundamentally based upon building relationships which is a paradigm shift away from viewing misbehaviours as a challenge to authority (Blood \& Thorsborne, 2006; Buckley \& Maxwell, 2007; Drewery \& Winslade, 2003; Hansen, 2005; McCluskey et al., 2008; Varnham, 2005). It is a process in which both the offender and the offended are given the opportunity to restore their relationship, a practice that also aligns with the key competencies in the curriculum of relating to others. Restorative practices and conversations allow schools to create a shared vision with their communities and students, and gain commitment from all

\footnotetext{
${ }^{3}$ Customs and practices
} 
parties towards resolution (Ashworth, Van Bockern, Ailts, Donnelly, \& Ericks, 2008; Macfarlane \& Margrain, 2011). Restorative practices requires a paradigm shift in ways behaviours are viewed and dealt with which can mean reconceptualising discipline policies in schools and revisiting the Ministry of Education's disciplinary guidelines. Schools in New Zealand have been implementing restorative practices in different ways, from having restorative conversations at a classroom level to restorative conferences in which representatives from whānau and the wider community are involved (Berryman \& Bateman, 2008; Buckley \& Maxwell, 2007; Gattung, 2007; Margrain \& Dharan, 2011; Steadman, 2008; Wearmouth et al., 2007). Despite having sound reconciliatory principles, and fairly successful projects in school under the aegis of Restorative Conferences in School (Te Hui Whakatika), there has not been a systematic and sustained implementation of this approach in New Zealand schools (Varnham, 2008).

\section{Positive behaviour support}

School-wide positive behaviour support (SWPBS) or Positive Behaviour Support (PBS) is an approach, under the Positive Behaviour for Learning (PB4L) initiatives and has been made available to a number of schools in New Zealand by the Ministry of Education since 2010. Following a hui - Taumata Whanonga - of multiple stakeholders concerned with increasing levels of suspensions and stand-downs, a multi-layered initiative has been established by the Ministry of Education. ${ }^{4}$ Initial reports from certain regions in the country show a decline in the suspension rates in schools involved in a restorative approach to discipline as part of their positive support initiatives (M. Corrigan, personal communication, December 9, 2012). While the evaluation in New Zealand on outcomes for students is still at an emerging stage, evaluations of the programme internationally suggest that SWPBS can be successful in addressing student behaviours provided it is implemented with fidelity (Cheney, Lynass, Flower, Waugh, \& Iwaszuk, 2010; Flannery, Sugai, \& Anderson, 2009; Simonsen et al., 2012; Vincent \& Tobin, 2011; Walker, Cheney,

\footnotetext{
${ }^{4}$ Details of the programme can be viewed in www.minedu.govt.nz
} 
Stage, Blum, \& Horner, 2005). But in order to implement PBS successfully requires the commitment and desire of all staff in a school to address challenging behaviours in less punitive ways (Meyer \& Evans, 2012a; Savage et al., 2011). Such schools will require transparency in ways they track the behaviours and monitor the progress by sharing it with their students. Schools with restorative ways to deal with problem behaviours have "fair and transparent rules for student conduct" with clear consequences for breaking them (Meyer \& Evans, 2012b, p. 127). The PB4L initiatives are still in their early stage in our schools and the empirical evidence in time will reveal its impact on students' disciplinary outcomes.

\section{Conclusion}

In conclusion, the fundamental principles of in-school disciplinary approaches are to empower students and equip them with the social nuances needed to problem solve and deal with conflicting situations, and to proactively manage behaviours that become barriers to learning and prevent their occurrence. Schools in lower socio-economic areas are generally associated with having more students suspended or expelled. But the opposite is not entirely true. The number of disengaged students is relatively low, underscoring the fact that disengagement from learning is deep-rooted within a secondary school context, exacerbated by its structure, focus, pedagogy, and notions of 'zero tolerance'. If the imperative is for student engagement figures to increase, then surely there must be a concerted effort to think and work differently in the ways that we approach disciplinary matters in schools. As Ainscow (2012) observes, perhaps we need to remove the arbitrary boundaries between and among schools, communities and administrators, allowing for successful practices of engaging students to be shared by schools working together. The example of four schools in the Nelson region coming together along with the community as part of the PB4L initiative (Bleasdale, 2012) could be a promising start of a collaborative approach to increase students' engagement and stay in schools.

If other schools have the will to collaborate and engage in innovative practices, is there a way for them to do it? Or will the 
competitive nature of Tomorrow's Schools, often identified as a deterrent for schools working collaboratively, be a barrier? The Ministry of Education's goal for all students having to obtain NCEA Level 2 is indeed noteworthy; but to meet this goal it is vital that students remain in school and the current high numbers of disengaged 14-year olds is unacceptable. Therefore, rather than putting the cart before the horse, schools must be encouraged and supported to keep students engaged in their learning, which will require removing the barriers to ways we currently think and act. We have the evidence of what works and what does not in terms of addressing student (mis)behaviours; intolerance is unlikely to produce academic, economic or social gains. Instead, as a school, as a community, and as a society we will need to invest time and energy in keeping children and young people more involved in their learning. Through an inschool approach, the authors are calling for schools to shape their practices in dealing with behaviours in a more democratic and restorative manner.

The notion of dealing with unacceptable behaviours in-house is not a model with a recipe. Rather, it is learning from what has been ineffective and moving to a paradigm dictated by an ethos of emotional, social, physical, and academic care to improve the educational engagement of those who are over-represented currently in the disciplinary statistics. Establishing a non-stigmatising in-school disciplinary approach requires strategic and systemic planning that includes engaging and collaborating with families. In-school approaches should to be developed within the context of each school and its community and, most importantly, be culturally sensitive and responsive. The key though is to design an approach with input from all staff, students, and families to ensure ownership and sustainability of such practices. As scholars in the field reiterate, let us constantly remind ourselves to problematise the behaviours and not the students. Once these necessary tenets are embedded in the ethos of schools and schools are in turn supported through policies, professional support and resources, then it is likely that more students will remain connected to their learning. Until then the question remains, where there is a will is there a way? 


\section{References}

Ainscow, M. (2012). Moving knowledge around: Strategies for fostering equity within educational systems. Journal of Educational Change, Online. doi:10.1007/s10833-012-9182-5

Ashworth, J., Van Bockern, S., Ailts, J., Donnelly, J., \& Ericks, K. (2008). The restorative justice center: An alternative to school detention. Reclaiming Children and Youth, 17(3), 22-27.

Becroft, A. (2012). Schools at front line. (Broadcast on National Radio). Retrieved from http://www.radionz.co.nz/news/national/110982/schoolsuspensions-low.

Berryman, M., \& Bateman, S. (2008). Effective bicultural leadership: A way to restore harmony at school and avoid suspension. Set: Research Information for Teachers, 1, 25-29.

Bleasdale, K. (2012). Bringing PB4L into the community. Education Gazette, 91(12), 10-11.

Blood, P., \& Thorsborne, M. (2006). Overcoming resistance to whole-school uptake of restorative practices. Paper presented at The Next Step: Developing Restorative Communities, Part 2, Bethlehem, Pennsylvania, USA.

Brooking, K., Gardiner, B., \& Calvert, S. (2009). Background of students in alternative education: Interviews with the selected cohort. Wellington: Ministry of Education.

Buckley, S., \& Maxwell, G. (2007). Respectful schools - Restorative practices in education: A summary report. Wellington: School of Government, Victoria University of Wellington.

Casella, R. (2003). Zero tolerance policy in schools: Rationale, consequences and alternatives. Teachers College Record, 105(5), 872-892.

Casey, C. (1994). Suspensions and expulsions in New Zealand state schools. New Zealand Annual Review of Education, 3, 253-284.

Cavanagh, T. (2007). Focusing on relationships creates safety in schools. Set: Research Information for Teachers, 1, 31-44.

Cavanagh, T. (2009). Restorative practices in schools: Breaking the cycle of student involvement in child welfare and legal systems. Protecting Children, 24(4), 53-60.

Charlton, T., Panting, C., \& Willis, H. (2004).Targeting exclusion, disaffection and truancy in secondary schools. Emotional and Behavioural Difficulties, 9(4), 261-275.

Cheney, D., Lynass, L., Flower, A., Waugh, M., \& Iwaszuk, W. (2010). The Check, Connect, and Expect Program: A targeted, tier 2 intervention in the school wide positive behaviour support mode. Preventing School Failure, 54(3), 152-158. 
Dickinson, M. C., \& Miller, T. L. (2006). Issues regarding in-school suspensions and high school students with disabilities. American Secondary Education, 35(1), 72-83. doi:10.1080/00131910120055598

Drewery, W., \& Winslade, J. (2003). Developing restorative practices in schools: Flavour of the month or saviour of the system? Paper presented at the AARE/NZARE Conference, Auckland.

Evans, I. M., \& Harvey, S. T. (2012). Warming the emotional climate of the primary school classroom. Wellington: Dunmore.

Flannery, K. B., Sugai, G., \& Anderson, C. M. (2009). School-wide positive behaviour support in high school. Journal of Positive Behavior Interventions, 11(3), 177-185. doi: 10.1177/1098300708316257

Fletcher, K. (2012) Suspensions hit Maori, Pasifika boys hardest. Retrieved August 2, 2012, from Stuff.co.nz.

Gattung, A. (2007). Restorative justice programmes for students: Sabbatical report to education leaders. Retrieved December 19, 2011, from http://www.educationalleaders.govet.nz.

Glynn, T., \& Berryman, M. (2005). Understanding and responding to students' behaviour difficulties. In D. Fraser, R. Moltzen, \& K. Ryba (Eds.), Learners with special needs in Aotearoa New Zealand ( ${ }^{\text {rd }}$ ed., pp. 294-315). Palmerston North: Dunmore Press.

Gootman, M. (1998). Effective in-house suspension. Educational Leadership, 56(1), 39-41.

Gregory, A., Cornell, D., \& Fan, X. (2011). The relationship of school structure and support to suspension rates for black and white high school students. American Educational Research, 48(4), 904-934.

Haley, N., \& Watson, D. (2000). In-school literacy extension: Beyond in-school suspension. Journal of Adolescent \& Adult Literacy, 43(7), 654-661.

Hallam, S., \& Castle, F. (2001). Exclusion from school: What can help prevent it? [Article]. Educational Review, 53(2), 169-179.

Hansen, T. (2005). Restorative justice practices and principles in schools. Minnesota: University of Minnesota, College of Human Ecology.

Hemphill, S. A., Herrenkohl, T. I., Plenty, S. M., Toumborou, J. W., Catalano, R. F., \& McMorris, B. J. (2012). Pathways from school suspension to adolescent nonviolent antisocial behavior in students in Victoria, Australia and Washington State, United States. Journal of Community Psychology, 40(3), 301-317.

Hemphill, S., Toumbourou, J., Smith, R., Kendall, G., Rowland, B., Freiberg, K., \& Williams, J. (2010). Are rates of school suspension higher in socially disadvantaged neighborhoods? An Australian study. Health Promotion Journal of Australia, 21(1), 12-18. 
Hilton, Z. (2006). Disaffection and school exclusion: Why are inclusion policies still not working in Scotland? Research Papers in Education, 21(3), 295-314.

Hyman, I. A., \& Perone, D. C. (1998). The other side of school violence: Educator policies and practices that may contribute to student misbehavior. Journal of School Psychology, 36(1), 7-27. doi: 10.1016/s0022-4405(97)87007-0

Kajs, L. T. (2006). Reforming the discipline management process in schools: An alternative approach to zero tolerance. Education Research Quarterly, 29(4), 16-27.

Macfarlane, A. H., \& Margrain, V. (2011). He Tapuwae o Mua: Footsteps towards responsive engagement with challenging behaviour. In V. M. A. H. Macfarlane (Ed.), Responsive pedagogy: Engaging restoratively with challenging behaviour (pp. 7-27). Wellington: NZCER.

MacFarlane, A., Hendy, V., \& Macfarlane, S. (2010). Young people experiencing behavioural difficulties: Discourses through the decades. Kairaranga, 11(2), 5-15.

Mallard, T. (2001). New government initiative to tackle school suspensions. Retrieved January 26, 2012, from http://www.beehive.govt.nz/node/10256.

Margrain, V., \& Dharan, V. (2011). Connecting curriculum. In V. Margrain \& A. MacFarlane (Eds.), Responsive pedagogy for teachers engaging with challenging behaviour (pp. 64-82). Wellington: NZCER.

Martinez, S. (2009). A system gone berserk: How are zero-tolerance policies really affecting schools? Preventing School Failure, 53(3), 153-158.

Mayer, G. R. (2001). Antisocial behavior: Its causes and prevention within our schools. Education \& Treatment of Children, 24(4), 414.

McCluskey, G., Lloyd, G., Kane, J., Riddell, S., Stead, J., \& Weedon, E. (2008). Can restorative practices in schools make a difference? Educational Review, 60(4), 405-417.

McGee, D. (2012). Call for curbs on school exclusions. Downloaded from http//www.stuff.co.nz 16/2/2012

Meyer, L., \& Evans (2012a). The school leader's guide to restorative school discipline. Thousand Oaks, CA: Corwin Press.

Meyer, L., \& Evans, I. (2012b). The teacher's guide to restorative classroom discipline. Thousand Oaks, CA: Corwin Press.

Michail, S. (2011). Understanding school responses to students' challenging behaviour? A review of literature. Improving Schools, 14(2), 156-171.

Ministry of Education. (2009). Guidelines for principals and boards of trustees on stand-downs, suspensions, exclusions and expulsions. Wellington: Author.

Ministry of Education. (2012). Stand-downs, suspensions, exclusions and expulsions from school. Retrieved August 10, 2012 from http:www. educationcounts.govt.nz/indicators/main/student-engagement. 
Monroe, C. (2005). The cultural context of 'disruptive behaviour': An overview of research considerations for school educators. Improving Schools, 8(2), 153-159. doi: 10.1177/1365480205057704

Monroe, C. (2006). African American boys and the discipline gap: Balancing educators' uneven hand. Education Horizons, 84(2), 102-111.

Morris, R., \& Howard, A. (2003). Designing an effective in-school suspension program. The Clearing House, 76(3), 156-159.

O'Brien, P., Thesing, A., \& Herbert, P. (2001). Alternative education: Literature review and report on key informants' experiences. Wellington: Ministry of Education.

Parffrey, V. (1994). Exclusion: Failed children or systems failure? School Organization, 14(2), 107.

Parsons, C. (2011). Strategic alternatives to exclusion from school $\left(2^{\text {nd }}\right.$ ed.). UK: Trentham Books.

Peguero, A., \& Shakarkhar, Z. (2011). Latino/a student misbehavior and school punishment. Hispanic Journal of Behavioral Sciences, 33(1), 54-70.

Rae, K. (1999). Stand downs, suspensions and exclusions: Potential impacts of the 1998 Education Amendment (No. 2) Act. New Zealand Annual Review of Education, 8, 27-44.

Reinke, W., \& Herman, K. (2002). Creating school environments that deter antisocial behaviours in youth. Psychology in the Schools, 39(5), 549-559.

Riordan, G. (2006). Reducing student 'suspension rates' and engaging students in learning: Principal and teacher approaches that work. Improving Schools, 9(3), 239-250.

Sanders, D. (2001). A caring alternative to suspension. The Education Digest, 51-54.

Savage, C., Lewis, J., \& Colless, N. (2011). Essentials for implementation: Six years of school wide positive behaviour support in New Zealand. New Zealand Journal of Psychology, 40(1), 29-37.

Shirley, E. L. M., \& Cornell, D. G. (2012). The contribution of student perceptions of school climate to understanding the disproportionate punishment of African American students in a middle school. School Psychology International, 33(2), 115-134. doi:10.1177/0143034311406815 Simonsen, B., Eber, L., Black, A., Sugai, G., Lewandowski, H., Sims, B., \& Myers, D. (2012). Illinois state-wide positive behavioral interventions and supports: Evolution and impact on student outcomes across years. Journal of Positive Behavior Interventions, 14(1), 5-16.

Skiba, R. (2000). Zero tolerance, zero evidence: An analysis of school disciplinary practice (Policy Research Report). Bloomington: Indiana University.

Skiba, R., \& Peterson, R. (2003). Teaching the social curriculum: School discipline as instruction. Preventing School Failure, 47(2), 66. 
Skiba, R., \& Sprague, J. (2008). Safety without suspensions. Educational Leadership, 66(1), 38-43.

Skiba, R., Michael, R., Nardo, A., \& Peterson, R. (2002). The color of discipline: Sources of racial and gender disproportionality in school punishment. The Urban Review, 34(4), 317-342.

Skiba, R., Simmons, A., Staudinger, L., Rausch, M., Dow, G., \& Feggins, R. (2003). Consistent removal: Contributions of school discipline to the school-prison pipeline. Paper presented at the School to Prison Pipeline Conference, Harvard Civil Rights Project.

Sleeter, C. E. (Ed.). (2011). Professional development for culturally responsive and relationship-based pedagogy. New York: Peter Lang.

Steadman, G. (2008). Investigating restorative justice models and their application in primary schools: Sabbatical report to educational leaders. Retrieved from http://www.educationalleaders.govt.nz

Sullivan, J. S. (1989). Elements of a successful in-school suspension program. NASSP Bulletin, 73(32), 32-38.

Varnham, S. (2005). Seeing things differently: Restorative justice and school discipline. Education and the Law, 17(3), 87-104.

Varnham, S. (2008). Keeping them connected: Restorative justice in schools in Australia and New Zealand: What progress? Australia \& New Zealand Journal of Law \& Education, 13(1), 71-82.

Vavrus, F., \& Cole, K. (2002). "I didn't do nothin": The discursive construction of school suspension. The Urban Review, 34(2), 87-111.

Vincent, C. G., \& Tobin, T. J. (2011). The relationship between implementation of School-Wide Positive Behavior Support (SWPBS) and disciplinary exclusion of students from various ethnic backgrounds with and without disabilities. Journal of Emotional and Behavioral Disorders, 19(4), 217-232. doi: 10.1177/1063426610377329

Vulliamy, G., \& Webb, R. (2000). Stemming the tide of rising school exclusions: Problems and possibilities. British Journal of Educational Studies, 48(2), 119-133.

Walker, B., Cheney, D., Stage, S., Blum, C., \& Horner, R. H. (2005). School wide screening and positive behavior supports. Journal of Positive Behavior Interventions, 7(4), 194-204. doi: 10.1177/10983007050070040101

Wearmouth, J., Mckinney, R., \& Glynn, T. (2007). Restorative justice in schools: A New Zealand example. Educational Research, 49(1), 37-49. 


\section{Appendix One}

Stand-down is the formal removal of a student from school for a specified period. Students cannot be stood down for more than 5 days in any school term or for more than 10 days in a year. Students can return automatically to school following a stand-down.

Suspension is a formal removal of a student from school until the school board of trustees decides the outcome of the suspension meeting. The board can either lift the suspension, with or without conditions, or permanently terminate the enrolment of the student.

Exclusion is when a student is suspended and under the age of 16 and the board of trustees terminates enrolment with the requirement that the student be enrolled elsewhere.

Expulsion occurs if a student who is 16 years or over is suspended and the board of trustees terminate enrolment. The principal or Ministry of Education are not obligated to find the pupil a new school in this instance but the pupil may choose to seek another school themselves.

Continual Disobedience is presented as one of the main behaviours that result in out-of-school discipline. It is when a student deliberately and regularly fails to do what they are told. There must be an element of wilful defiance of the school's authority (Youth Law New Zealand; Ministry of Education, 2009).

Age-standardised rates are used as most stand-downs, suspensions, and exclusions occur at ages 13-15, while most expulsions occur at 16. As stand-downs are highest for ages 13 to 15, standardising for age will remove any differences due to one group having a younger or older population than other groups or if the overall age distribution has changed from year to year.

(Source: Ministry of Education Guidelines for principals and boards of trustees on stand-downs, suspensions, expulsions and exclusions \& www.educationcounts.govt.nz). 


\section{The authors}

Vijaya Dharan is currently a lecturer in the School of Psychology and Pedagogy, Victoria University of Wellington. She is involved in the training of educational psychologists and also teaches undergraduate teacher training and post graduate courses. As a registered psychologist with a she has worked for nearly 15 years with teachers, parents, schools and early childhood services to make learning accessible for students who have significant behavioural and learning challenges. The experiences gained in working with children and families have reinforced to her that understanding lived experiences and restoring and restorying lives of some children is pivotal for their long term well being and thereby reducing their exclusion from learning opportunities and society as a whole. As a passionate advocate for social justice, she is deeply interested in the area of "learning for all" and in particular, the various beliefs, perceptions and attitudes of educators that can enhance or hinder this process.

\section{Email: vijaya.dharan@vuw.ac.nz}

Luanna H. Meyer is Emerita Professor of Education at Victoria University. Her research is focused on validating practical, evidence-based approaches for inclusive schools. Currently, she is Editor-in-Chief for Oxford University Press's OBO Education and is a member of the Technical Review Committee on Behavior for the National Center for Students with Disabilities who Require Intensive Interventions in the U.S.A. She has been invited to speak in eight countries and 30 US states about her work, and she has published more than 120 journal articles and book chapters. Her 12 books include The School Leader's Guide to Restorative School Discipline; The Teacher's Guide to Restorative Classroom Discipline; Making Friends: The Influences of Culture and Development; and Critical Issues in the Lives of People with Severe Disabilities.

\section{Email: luanna.meyer@vuw.ac.nz}

Nicole Mincher graduated in 2011 with a Bachelor of Science in Psychology and Education. In 2012 she completed the first step of the Educational Psychology training by gaining her Postgraduate Diploma in professional development. Nicole is currently undertaking her Masters of Educational Psychology where her research interest lies in equality, social justice and transparency in education. 